\title{
Energy Conservation through Motors in Pakistan's Industrial Sector- Need to Use of Energy Efficient Motors
}

\author{
Mahesh Rathi \\ Department of Electrical Engineering, Mehran \\ University of Engineering \& Tech Jamshoro, \\ Pakistan \\ Pervez Hameed Shaikh \\ Department of Electrical Engineering, Mehran \\ University of Engineering \&Tech Jamshoro, \\ Pakistan
}

\author{
Faheemullah Shaikh \\ Department of Electrical Engineering, Mehran \\ University of Engineering \& Tech Jamshoro, \\ Pakistan \\ M. Aslam Uqailli \\ Department of Electrical Engineering, Mehran \\ University of Engineering \& Tech Jamshoro, \\ Pakistan
}

\begin{abstract}
Pakistan is an energy deficit country. The purpose of this research paper is to shed light on current Pakistan's electrical energy conservation efforts and on potential of electrical energy saving in different sectors, this paper also describes the usage of energy efficient motors technologies for the industrial processes because $30 \%-70 \%$ of electricity is consumed by motors load. Different countries use their codes, standards and regulation as voluntarily, mandatorily to conserve electricity but Pakistan yet lacks behind.
\end{abstract}

\section{Keywords}

Energy Efficiency in motors, industrial motors, Energy audit

\section{INTRODUCTION}

Global warming, fossil fuel depletion, the growth of new large economies interlace the uncomfortable situation on world's energy outlook, this ultimately makes higher energy commodity prices and economic disruption to the society. The following Fig 1 shows the oil and gas production and demand level, the increasing line showing the demand is increasing

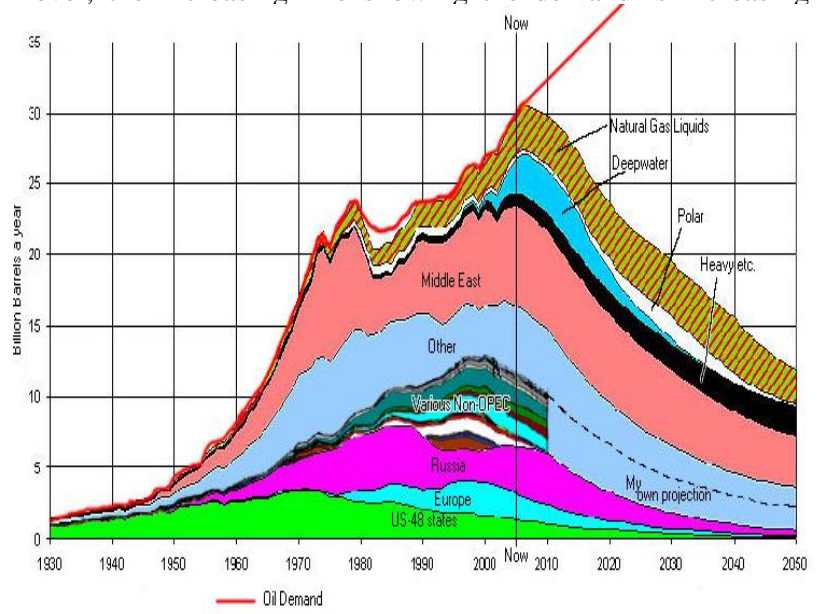

Fig 1: Global Oil and gas production and demand

Pakistan's economy activity is always remain debatable on the impact of higher oil prices, the crude oil prices goes up from 33 US dollar in January 2009 to 120 US dollar [3]. The impact of increased oil prices brings high inflation, high budget deficit and slow down the foreign exchange rates putting expensive import and ultimately affect the generation of electricity. As the industrial sector consumes large amount of energy in motors, the efficient use of energy will play an important role to reduce the energy use and emission that releases to atmosphere. Energy efficient motors are generally 4-5\% more efficient than standard motor, so improving energy efficiency of motors in industrial sector will make sustainable development for any country.

\section{ENERGY PAKISTAN \\ SITUATION}

IN

Energy shortage in Pakistan as a whole started in FY 2007 worsened the situation during FY 2008-FY 2011. The energy supply deficit reached $5000 \mathrm{MW}$ as it can be seen by the figure 02 . This extended power outage lasting more than 12 hours a day in rural areas and 6-8 hours in urban areas have put the negative effect and reduces the socio economic development, these indeed putting industries off or reduces their production level, impacts on unemployment and reduces the income of workers $[4,5]$.

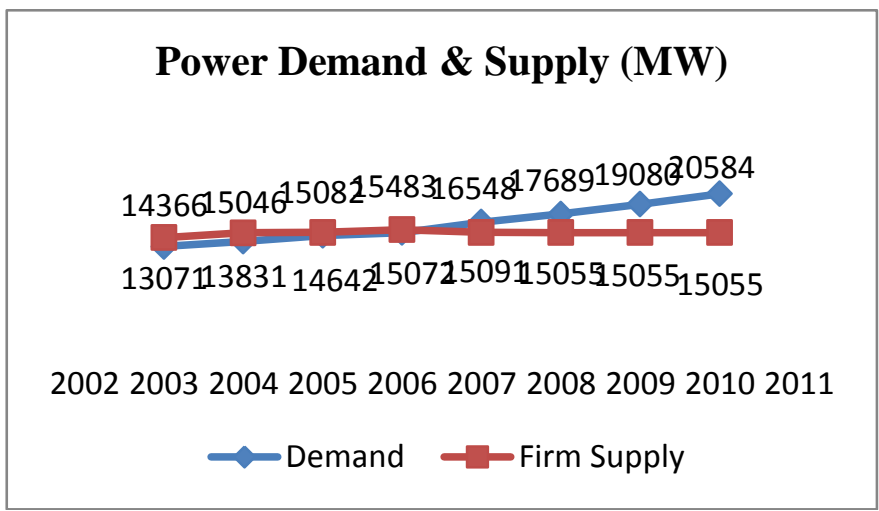

Fig 2: Power Demand and Firm Supply

In this year 2012, Pakistan government trying to take various measures to tackle the situation, while energy efficiency has also been identified as an effective tools for short and medium term for the economic growth. 


\subsection{Energy consumption in Pakistan by sector wise}

Figure 03 shows the energy consumption in Pakistan; from the figure it can be seen that industrial sector is larger consumer of energy includes oil, gas, electricity etc [6].

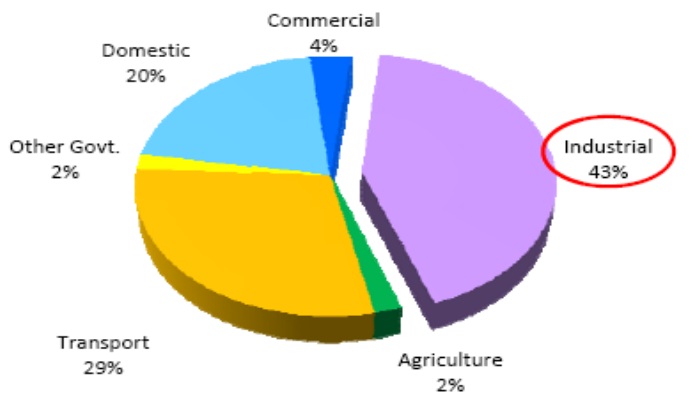

Fig 3: Sector wise break up of Energy consumption

\subsection{Electricity consumption in Pakistan by sector}

Fig. 04 shows the electricity consumption by the sector it can be observed from figure that industrial sector is second larger consumer of electricity in Pakistan which consumes about $27.5 \%$ of energy where as the agriculture consumes $12.5 \%$ of the electricity. The main load to these sectors is electrical motor about $30 \%$ to $80 \%$, in industry it used for different rotating different machines for process, in pumps, compressors and in fans etc whereas in agriculture it uses for motor-pump driven system [7].

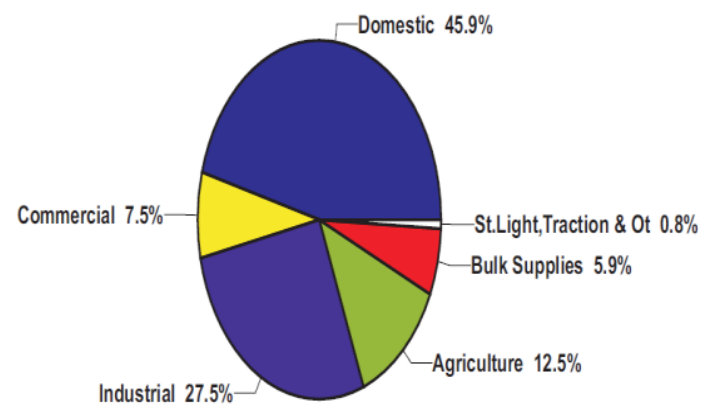

Fig 4: Sector- wise breakup of electricity consumption
The Industrial sector is the biggest consumer of energy, it consumes $43 \%$ of total energy and as for electricity concerned the industrial sector is second large consumer, it consumes $27.5 \%$ of electricity. Being a larger energy consumer it accumulated only 19\% GDP in the FY 2008 (ADB) due to inefficient technology and decaying of infrastructure, lesser energy productivity affects the industrial competitiveness.

According to the report of Asian Development Board, Pakistan's electricity saving potential in the industrial sector is expected $11.2 \%$ for ten year forecasted period from 2009 to 2019 with the investment of 1850 million US dollar, and major energy efficiency improvement is observed in the textile, iron, steel and sugar industries as shown in Table 1 [6].

Worldwide industrial sector consumes a substantial proportion $30 \%$ to $70 \%$ of electricity in motors load; out of which Malaysia 48\%, UK 50\%, US 75\%, India 70\%, Turkey and EU $65 \%$, Jordon $31 \%$ and Canada $80 \%$ [8].

According to Proposed work plan for energy efficiency policy opportunities for electric motor-driven system from International Energy Agency about $15 \mathrm{TWh} / \mathrm{year}$ is being consumed in Paksitan's all sectors inculding, industry, agriculture, resedential and transport that is about $38.3 \%$ of toal demand of electricity of the country[9]

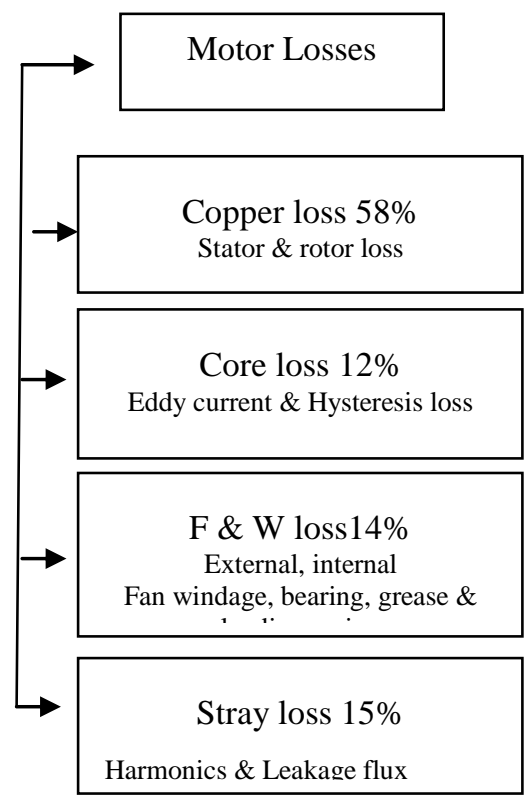

Fig 5: Technical motors losses

Table 1. Energy consumption, realizable saving and investment requirement for electricity in industry.

\begin{tabular}{|c|c|c|c|c|c|c|}
\hline \multicolumn{2}{|c|}{ Electricity Forecast } & Iron \& Steel & Paper & Textile & Sugar & Other industries \\
\hline \multicolumn{2}{|c|}{$\begin{array}{l}\text { Electricity consumed } \\
\text { FY } 2008(\mathrm{GW})\end{array}$} & 2704 & 572 & 5318 & 150 & 11985 \\
\hline \multicolumn{2}{|c|}{$\begin{array}{c}\text { Electricity consumption Forecast, } \\
\text { FY } 2019 \text { ( GW) }\end{array}$} & 5475 & 1157 & 10768 & 304 & 24267 \\
\hline \multirow{3}{*}{$\begin{array}{l}\text { Energy efficiency } \\
\text { potential }(\%)\end{array}$} & Technical & 12 & 0 & 7 & 0 & 10 \\
\hline & Realizable & 50 & 0 & 50 & 0 & 35 \\
\hline & Effective & 6 & 0 & 4 & 0 & 3 \\
\hline \multicolumn{2}{|c|}{$\begin{array}{c}\text { Realizable savings FY } \\
2019(\mathrm{GW})\end{array}$} & 166 & -- & 186 & -- & 817 \\
\hline \multicolumn{2}{|c|}{ Investment required \$ million } & 17 & -- & 42 & -- & 183 \\
\hline \multicolumn{2}{|c|}{ Simple Payback (yrs) } & 1.3 & -- & 2.9 & -- & 2.9 \\
\hline
\end{tabular}


Table 2. Different efficiency clauses of three phase induction motors

\begin{tabular}{|c|c|c|c|c|c|}
\hline \multicolumn{3}{|c|}{2 Pole } & \multicolumn{3}{|c|}{4 Pole } \\
\hline \multirow[b]{2}{*}{$\mathrm{kW}$} & \multicolumn{2}{|c|}{ Efficiency $(\%)$} & \multirow[b]{2}{*}{$\mathrm{kW}$} & \multicolumn{2}{|c|}{ Efficiency (\%) } \\
\hline & $\begin{array}{l}\text { Eff1 or above } \\
\text { (High) }\end{array}$ & $\begin{array}{c}\text { Eff } 2 \text { / Eff } 3 \\
\text { (standard) }\end{array}$ & & $\begin{array}{c}\text { Eff1 or above } \\
\text { (High) }\end{array}$ & $\begin{array}{c}\text { Eff } 2 \text { / Eff } 3 \\
\text { (standard) }\end{array}$ \\
\hline 1.1 & 82.8 & 76.2 & 1.1 & 83.8 & 76.2 \\
\hline 1.5 & 84.1 & 78.5 & 1.5 & 85.0 & 78.5 \\
\hline 2.2 & 85.6 & 81.0 & 2.2 & 86.4 & 81.0 \\
\hline 3.0 & 86.7 & 82.6 & 3.0 & 87.4 & 82.6 \\
\hline 4.0 & 87.6 & 84.2 & 4.0 & 88.3 & 84.2 \\
\hline 5.5 & 88.6 & 85.7 & 5.5 & 89.2 & 85.7 \\
\hline 7.5 & 89.5 & 87.0 & 7.5 & 90.1 & 87.0 \\
\hline 11 & 90.5 & 88.4 & 11 & 91.0 & 88.4 \\
\hline 15 & 91.3 & 89.4 & 15 & 91.8 & 89.4 \\
\hline 18.5 & 91.8 & 90.0 & 18.5 & 92.2 & 90.0 \\
\hline 22 & 92.2 & 90.5 & 22 & 92.6 & 90.5 \\
\hline 30 & 92.9 & 91.4 & 30 & 93.2 & 91.4 \\
\hline 37 & 93.3 & 92.0 & 37 & 93.6 & 92.0 \\
\hline 45 & 93.7 & 92.5 & 45 & 93.9 & 92.5 \\
\hline 55 & 94.0 & 93.0 & 55 & 94.2 & 93.0 \\
\hline 75 & 94.6 & 93.6 & 75 & 94.7 & 93.6 \\
\hline 90 & 95.0 & 93.9 & 90 & 95.0 & 93.9 \\
\hline
\end{tabular}

\section{LOSSES IN MOTORS}

Electric motor energy analysis and their associated losses are taken from specialized literature, and ways to reduce it is also explained $[10,11]$.The figure 05 shows the losses which occurs in the standard types of motors used previously. A few years back the manufacture's goal was to produce the motor that cost less in production thus using low grade material and offer reduced efficiency but now a days the goal is to use of high grade material so that reduce the electricity cost during motor's life.

The most widely used techniques in manufacturing by use of high grade material other parameter to reduce the losses hence the motors are divided by different efficiency clauses like standard motor, high efficiency motor or energy efficient motor and premium motors. These following losses notified from specialized literature [10, 11, and 12].

\section{ENERGY EFFICIENT MOTOR}

An improved design, manufacturing and material techniques enables the energy efficient motors to perform more work onto per unit electricity consumption. Energy efficient motor has

- High magnetic properties

- Reduced rotor and stator gap

- High laminated stator winding

- Reduced heating and fan losses

- Better insulation.

\subsection{Standard and energy efficient motors efficiency clauses}

Motors Efficiency labeling scheme Brook Crompton shows the different efficiency clauses of three phase induction motors as shown in Table 2. [13].

\section{MOTOR SYSTEM AND OPTION FOR ENERGY EFFICIENCY}

The concept of energy efficiency forced by literature like ( Mckane et al 2007, Oikonomon et al 2009, Sola \& Xavier 2007, R. Saidur 2010) , through the process of energy efficiency one can say that a product or process is energy efficient if compared with reference, the efficiency of motor are actually to be compared with new technology introduced or new motor with high reliability and manufactured warranties, there is different ways to improve energy efficiency in motors among the ways replacement of standard motors to high energy efficient motors is recommended [14].

\subsection{Energy efficiency policy}

Pakistan lacks an energy efficiency management system though a few of organization like ADB,NPO, ENERCON,AEDB etc are working on energy efficiency and conservation program but Energy consumption in different process or industries is not practically observed, according to Pakistan quality control and regularity authority the standard for motor is PS IEC: 60034/2007 (Part 1 to 4) but practically there is no implementation of this standard, not even rules and regulation on mandatory or even voluntarily to be set yet to implement whereas other countries are very much engage to set rules and regulation on the mandatory and voluntary basis.

\subsection{Cross country motors energy use and saving}

The industrial sector around the world consumes $30 \%-40 \%$ of global electricity and $30 \%$ to $70 \%$ of the total power of the nations is being consumed by electrical motor as specified in specialized literature, number of developed and developing countries like Brazil, Malaysia, Canada, America, China, India etc are involved to implement the projects for conservation of energy; Table 3 shows the agreement done by different countries [15]. 
Garcia et al in 2006 has taken 9000 industrial motors in Brazilian for the estimation of capital cost and dollar saving by analyzing the energy efficiency in electrical motor by replacing it with energy efficient motor, he concludes that industrial motor consumes $121 \mathrm{TWh} /$ year, energy saving and dollar saving for Brazilian country can be approximate $1621 \mathrm{GWh}$ per year with annual cost of 37 million US dollar [16].

Saidur et al in 2010 has done the case study for Malaysian industries' motors, he suggests if standard motors are low efficient and if it replaced with high efficient motors can save energy about $1575 \mathrm{GWh}$ for all category of motors for the year 2010 with 105 million US dollar to reduce the utility bills for the same period of time [17].

De Almeida et al has worked on standardization of the new energy efficient motors to put on work for the nation, according to his study in Oct 2001 manufactured or imported three phase induction motors ranging from $0.37 \mathrm{KW}$ to < 185Kw must fulfill MEPS requirement in Australia. In 2005 Australia come up with $10 \%$ share of premium efficiency, $32 \%$ and $58 \%$ as high and standard efficiencies of motors [18].

\section{MATHEMATICAL FORMULAS}

To work on efficient motors first it is required to find the existing efficiency of motors for that a few electrical parameter like, $I_{R}$ (real measured current), $I_{N}$ (nominal current) from manufacturer, $I_{0}$ (no load current from manufacturer or measured has to be find in order to find the real load of motors:

$$
\gamma=1+(1 / \alpha) * \operatorname{Ln}(\mathrm{IR} / \mathrm{IN})
$$

Load current parameter is measured by

$$
\alpha=-\operatorname{Ln}(\mathrm{Io} / \mathrm{IN})
$$

Io $=$ no load current

$\mathrm{I}_{\mathrm{N}}=$ nominal current

The electrical efficiency of different components is calculated by power output to power input

$$
\eta=\text { Pout } / \text { Pin }=(0.746 * \mathrm{PHP} * \gamma) / \mathrm{PR}
$$

$\mathrm{P}_{\mathrm{R}}=$ measured input power

$\mathrm{P}_{\mathrm{HP}}=$ output power

$\gamma=$ rated load $(\%)$

$\eta_{L}=$ exiting motor's efficiency

The IEE factor is the energy efficiency tells, percent of energy saved by replacement with new energy efficient motor, given by:

$$
\mathrm{IEE}=(1-\eta \mathrm{L} / \eta) * 100 \%
$$

\subsection{Motors investment value (MIV)}

Motor investment value is price plus installation charges, actually high efficient motors are more expensive about $20 \%$ than ordinary motors because it uses greater amount of copper and other mechanical parameters so as to increase the efficiency. Because of high price new high efficient motor are conflicting factor in industry.

\subsection{Energy saving $(\mathrm{kWh})$}

Energy saved values is the electrical unit saved. To find quantity of energy saved per year, compare standard motors efficiency with new one and motors operation hours with its real load values, QES is given by:

$$
\mathrm{QES}=0.746 * \mathrm{PHP} * \gamma * \mathrm{t} *(1 / \eta \mathrm{L}-1 / \eta)
$$

\subsection{Energy saved values (in Rs.)}

Energy saved values is given by multiplying the energy unit saved with tariff per kwh. The cost of electricity is different for peak demand and for off peak demands thus a particular motor for the same rating operating on same time will consumes same unit but giving the different values. In this study the cost for B3 industrial sector is taken form HESCO. The energy save values per year is given by following equation:

$$
\mathrm{ESV}=\mathrm{QES} * \mathrm{C}(\text { Rupees/year })
$$

Table 03. Motor efficiency voluntary agreement and regulation around the world [ 15].

\begin{tabular}{|c|c|c|}
\hline Country / region & $\begin{array}{c}\text { Mandatory agreement } \\
\text { (year of implementation) }\end{array}$ & $\begin{array}{c}\text { Voluntary agreements } \\
\text { (year of implementation) }\end{array}$ \\
\hline USA & $\begin{array}{c}\text { EPAct-high efficiency (1997) } \\
\text { NEMA Premium (2011) }\end{array}$ & NEMA Premium (2001) \\
\hline Canada & EPAct level high efficiency (1997) & NEMA Premium (2001) \\
\hline Mexico & EPAct level high efficiency (1998) & $\begin{array}{c}\text { Efficiency classification and market } \\
\text { reduction of Eff3 (1998) }\end{array}$ \\
\hline EU & - & Premium efficiency (2006) \\
\hline Australia & high efficiency (2006) & Premium efficiency (2006) \\
\hline New Zealand & high efficiency (2006) \\
\hline Brazil & $\begin{array}{c}\text { Standard efficiency (2002) } \\
\text { High efficiency (2009) }\end{array}$ \\
\hline China & $\begin{array}{c}\text { Standard efficiency (2002) } \\
\text { High efficiency (20011) }\end{array}$ \\
\hline Korea & Standard efficiency (2008) & Premium efficiency (2007) \\
\hline
\end{tabular}




\subsection{Payback period}

The payback period tells the invested money when to be returned back, installing the new energy efficient motor is costly so a huge amount of money is to be invested. The pay back or simple payback can be calculated by considering MIV and ESV, given by following equation.

$$
\mathrm{SPB}=\mathrm{MIV} / \mathrm{ESV}(\mathrm{yr})
$$

\section{TECHNICAL DATA FOR MOTORS}

In this research paper 180 motors are chosen which are 7.5 $\mathrm{kW}, 11 \mathrm{~kW}, 15 \mathrm{~kW}, 18 \mathrm{~kW}$ and $22 \mathrm{~kW}$ all are 3 phase induction motor, are ten years old and operating time for a whole year 8760 hrs. The nominal power, nominal current, no load current and actual power measured through Fluke power analyzer meter. The electricity per unit cost for B3 type connection is Rs $10 / \mathrm{KWh}$ according to Hyderabad Electric Supply Corporation (HESCO) in may 2011

Table 04. Three phase induction motors data from standard motors

\begin{tabular}{|c|c|c|c|c|c|}
\hline Motors & $\begin{array}{c}\text { Power } \\
\text { rated } \\
\text { (kw) }\end{array}$ & $\begin{array}{c}\text { Nominal } \\
\text { current } \\
\text { (amp) }\end{array}$ & $\begin{array}{c}\text { No } \\
\text { Load } \\
\text { current } \\
\text { (amp) }\end{array}$ & $\begin{array}{c}\text { Current } \\
\text { measured } \\
\text { (amp) }\end{array}$ & $\begin{array}{c}\text { Power } \\
\text { measured } \\
\text { (kw) }\end{array}$ \\
\hline M1 & 7.5 & 12.7 & 6.49 & 12 & 7.8 \\
\hline M2 & 7.5 & 12.7 & 7 & 11 & 6.72 \\
\hline M3 & 7.5 & 12.7 & 6.59 & 11.5 & 7.2 \\
\hline M4 & 7.5 & 12.7 & 6.49 & 11.3 & 7.1 \\
\hline M5 & 11 & 20.8 & 8.5 & 13.27 & 6.44 \\
\hline M6 & 11 & 19 & 8.5 & 17.2 & 11.21 \\
\hline M7 & 11 & 23 & 8.5 & 15.57 & 7.83 \\
\hline M8 & 11 & 19 & 8.5 & 11.8 & 6.36 \\
\hline M9 & 15 & 24.5 & 9 & 16.37 & 10.11 \\
\hline M10 & 15 & 24.5 & 9 & 16.17 & 9.9 \\
\hline M11 & 18.5 & 33.3 & 13 & 19.67 & 9.3 \\
\hline M12 & 18.5 & 33.3 & 13.1 & 21.17 & 10.8 \\
\hline M13 & 22 & 38 & 14 & 21.83 & 11.27 \\
\hline M14 & 22 & 38 & 13.5 & 22.6 & 12.45 \\
\hline M15 & 22 & 38 & 14.2 & 21.85 & 11.12 \\
\hline
\end{tabular}

Table 5 showing the author's calculation and new efficiency taken from European Union standard for Energy-efficiency policy opportunities as shown

Table 5. Calculation for standard motor's efficiency

\begin{tabular}{|c|c|c|c|c|c|}
\hline Motors & LF (\%) & Pout $(\mathbf{k w})$ & $\begin{array}{c}\text { Pin } \\
(\mathbf{k w})\end{array}$ & $\begin{array}{c}\text { Measured } \\
\text { Eff }(\boldsymbol{\%})\end{array}$ & $\begin{array}{c}\text { New Eff } \\
(\%)\end{array}$ \\
\hline M1 & 0.9 & 6.75 & 7.8 & 0.865 & 0.905 \\
\hline M2 & 0.78 & 5.82 & 6.72 & 0.866 & 0.905 \\
\hline M3 & 0.84 & 6.33 & 7.2 & 0.879 & 0.905 \\
\hline M4 & 0.82 & 6.16 & 7.1 & 0.86 & 0.905 \\
\hline M5 & 0.49 & 5.56 & 6.44 & 0.86 & 0.918 \\
\hline M6 & 0.87 & 9.8 & 11.21 & 0.87 & 0.918 \\
\hline M7 & 0.6 & 6.8 & 7.83 & 0.86 & 0.918 \\
\hline M8 & 0.48 & 5.4 & 6.36 & 0.85 & 0.918 \\
\hline
\end{tabular}

\begin{tabular}{|c|c|c|c|c|c|}
\hline M9 & 0.59 & 8.9 & 10.1 & 0.88 & 0.923 \\
\hline M10 & 0.5 & 8.7 & 9.9 & 0.88 & 0.923 \\
\hline M11 & 0.4 & 8.21 & 9.3 & 0.88 & 0.926 \\
\hline M12 & 0.51 & 9.59 & 10.84 & 0.88 & 0.926 \\
\hline M13 & 0.44 & 9.95 & 11.27 & 0.883 & 0.928 \\
\hline M14 & 0.49 & 11.14 & 12.45 & 0.894 & 0.928 \\
\hline M15 & 0.43 & 9.79 & 11.12 & 0.87 & 0.928 \\
\hline
\end{tabular}

As from above table the efficiency of existing motor is very low, whereas the new efficiency is determined from manufacturer's table for motor-driven system (paul-waide with international energy agency 2011).when the existing motor is replaced with energy efficient ones, it not only saves electricity units, rupees saving but also increased the efficiency of machines, result is presented in table 6 . Figure 6 and Table 7 are showing the overall energy saving in motors and comparison with motor investment and energy saving.

Table 6. Energy saving and pay back

\begin{tabular}{|c|c|c|c|c|}
\hline Motors & QES (kw) & ESV (Rs) & MIV (Rs) & $\begin{array}{c}\text { SPB } \\
\text { (years) }\end{array}$ \\
\hline M1 & 2991 & 29910 & 80000 & 2.6 \\
\hline M2 & 2475 & 24751 & 80000 & 3.2 \\
\hline M3 & 1787 & 17872 & 80000 & 4.4 \\
\hline M4 & 2549 & 25494 & 80000 & 3.1 \\
\hline M5 & 3263 & 32632 & 125000 & 3.8 \\
\hline M6 & 4631 & 46317 & 125000 & 2.6 \\
\hline M7 & 3661 & 36619 & 125000 & 3.4 \\
\hline M8 & 3652 & 36526 & 125000 & 3.4 \\
\hline M9 & 3975 & 39757 & 150000 & 3.7 \\
\hline M10 & 3874 & 38743 & 150000 & 3.8 \\
\hline M11 & 3786 & 37867 & 200000 & 5.2 \\
\hline M12 & 4190 & 41904 & 200000 & 4.7 \\
\hline M13 & 4739 & 47395 & 225000 & 4.7 \\
\hline M14 & 3878 & 38789 & 225000 & 5.8 \\
\hline M15 & 4918 & 49189 & 225000 & 4.5 \\
\hline
\end{tabular}

Table 7. Electricity consumed, saving and payback from high efficient motor

\begin{tabular}{|c|c|c|c|}
\hline $\begin{array}{c}\text { Electricity } \\
\text { consumed } \\
\text { (MWh/year) }\end{array}$ & $\begin{array}{c}\text { Electricity } \\
\text { Saved } \\
\text { (MWh/year) }\end{array}$ & $\begin{array}{c}\text { MIV } \\
\text { (Million } \\
\text { Rs.) }\end{array}$ & $\begin{array}{c}\text { Payback } \\
\text { (years) }\end{array}$ \\
\hline 3800 & 150 & 6.47 & 4.5 \\
\hline
\end{tabular}

Figure 6 representing the motor investment value purchased from market versus rupees saving by replacing the standard motor with energy efficient one. 


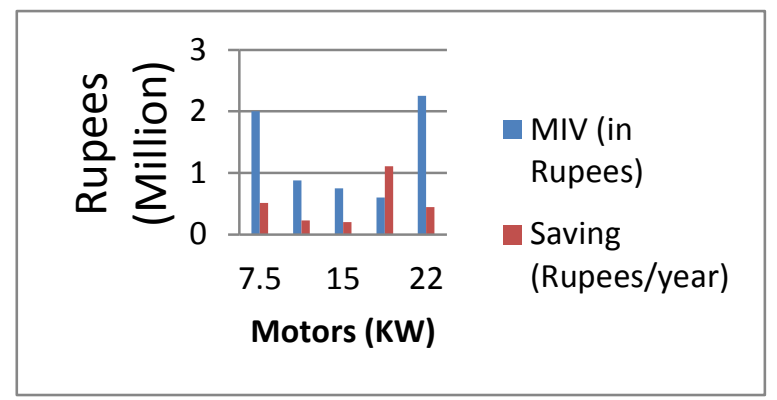

Figure 06. Motors investment versus saving in Rupees

\section{MOTOR ENERGY SAVING}

The following are different ways to improve the efficiency of overall industrial sector by reducing the electrical energy waste from motors by adopting energy saving strategies.

\subsection{Using Regulation}

\subsubsection{Approaches (mandatory/regulatory and voluntary)}

For public and private sector the mandatory and regulatory approaches increase their knowledge that certain level of MEPS (minimum energy performance standard) has been achieved nationally. By putting mandatory approaches one image of organization and of policy makers is been promoting and ultimately reduces the energy demands and $\mathrm{CO} 2$ emission factors. It is essential besides setting a minimum performance standard, there can be voluntary schemes for increased awareness and derive towards improvement. Furthermore mandatory/ regulatory measures can be classified (MEPs, Enforcement, Certification, Testing) where as voluntary approaches classified as (Labels, training and tools, public procurement programs).

\section{USA Energy Policy Act (EPACT-1992)}

In October 1997 it was enforced mandatory by USA that electrical motor either manufactured or imported should meet minimum energy efficiency performance standard levels. EPACT motors constitutes about $54 \%$ of motors share in market in 2009.

\section{NEMA - Premium (2002)}

National Electric Manufacturing Association (NEMA) introduces a scheme of premium higher efficiency motors because fewer utilities and industry association were promoting with higher efficiency than EPACT level. In 2005 NEMA premium motors constitutes the market share of $16 \%$ in USA and US decides that by 2011 NEMA premium level should be increased to Minimum energy performance standard for electrical motors.

\section{Mexico, Brazil and Canada}

Mexico Brazil both working to enhance the standardization of motors and have their own MEPS system. Currently Mexico is following NOM-016-ENERB 2002 matching with efficiency of same EPAct index. Mexico's standard has somewhat greater application as of EPAct that covering motor only ranging from $0.746 \mathrm{KW}$ to $373 \mathrm{KW}$. Canadian Standard Association sets their standard as of same as EPAct with slight difference that EPAct uses $50 / 60 \mathrm{~Hz}$ dual frequency electric motors.

\section{EU (Europe and Pakistan)}

The EU-CEMPS provides rating and identification of motors efficiency. Eff 1 is high index and Eff 2 motors with efficiency value between two levels of low and high and Eff 3 is classified as low efficient motors. This standard is been followed by 23 countries including Pakistan.

\subsubsection{Incentives}

The government should support the organization and manufacturer in the sense there should lesser taxes on materials purchased or imported. The government and R\&D provide loans and free audits and rebate for investments.

\subsubsection{Application of technology}

The organization should be aware and having high technical personal for auditing and using of proper technology to reduce the demand of electricity by putting VSD's, PF improvement or new HEM motors.

\subsubsection{By housekeeping}

Proper maintenance, switching off and on for auditing the equipment.

\section{CONCLUSION}

In the country like Pakistan where, industrial and agriculture sectors used motor they are old, re-winded, if purchased than due to low initial cost they are inefficient, if these sectors are to be audited a huge potential of electricity can be saved. It is suggested that the government should support and implement energy audit, energy efficiency and conservation efforts so that on voluntarily or mandatory action can be taken place in order to increase the competitiveness of industrial sector and fulfill the supply demand gap.

\section{REFERENCES}

[1] R. W. Bentley "Global oil \& gas depletion: an overview," Energy Policy, Vol. 30, pp. 189-205, 2002.

[2] SORRELL "An assessment of the evidence for a nearterm peak in global oil production," Energy policy Vol. 38 pp. $5290-5295,2010$.

[3] Pakistan Energy Yearbook 2009 "Ministry of Petroleum and Natural Resources, Hydro Carbon Development Institute of Pakistan".

[4] Muhammad Imtiaz Subhani "Energy short fall and its after effects" (A Case Study for Karachi City in context to Karachi Electric Supply Corporation) Science Series Data Report, paper no. 37663, 2012.

[5] Hasan "The energy short fall and its after effects" (a case study for Karachi city in context to Karachi electric supply corporation) Science Series Data Report, 42-49, 2012.

[6] Pakistan Sustainable Energy Efficiency Development Program, 2009. Project Number: ADB TA 7060-PAK

[7] R. Saidur "Energy, economic and environmental benefits of using high-efficiency motors to replace standard motors for the Malaysian industries" Energy policy Vol. 38, pp. 4617-4625, 2010. 
[8] R. Saidur "Energy consumption, energy savings, and emission analysis in Malaysian office buildings" Energy policy Vol.38, pp.4104-4113, 2009.

[9] Paul Waide. 2011 Energy-Efficiency Policy Opportunities for Electric Motor-Driven Systems. International Energy Agency".

[10] Jayamaha L. Energy efficient building systems. McGraw Hill Publisher, 2008.

[11] Ways to Minimize Motor Losses Bureau of Energy Efficiency (BEE) India; 2009.

[12] Losses of Electrical Motor given by Siemens on website shumaonline, 2009.

[13] Electric Motor MEPS Guide Book, 1st Edition by Zurich Switzerland 2009 "Electric Motor MEPS Guide introduction of new testing standards, efficiency classes, labels and minimum energy performance standards MEPS for electric motors in global markets"
[14] Antonio Vanderley Herrero Sola "A model for improving energy efficiency in industrial motor system using Multi Criteria Analysis" Energy Policy Vol. 39, pp.3645-3654, 2011.

[15] Appliance Energy Efficiency Standards and Labeling Report 2008 "Electric Motors Alignment of Standards and Best Practice Programs within APEC", Workshop in Japan by APEC Energy Working Group.

[16] Agenor Gomes Pinto Garcia "Energy-efficiency standards for electric motors in Brazilian industry" Energy Policy Vol. 35, pp.3424-3439, 2007.

[17] T.M.I. Mahlia "Energy, economic and environmental benefits of using high-efficiency motors to replace standard motors for the Malaysian industries" Energy Policy, Vol.38 pp.4617-4625, 2010

[18] De Almeida "Citing the SEEEM Harmonization Initiative Energy- Efficiency Policy Opportunities for Electric Motor-Driven Systems" International Energy Agency Working paper, 2011. 